Misbah, A.S.M., Disaratna, V., Ganeshu, P. and Nazeer, F.S., 2019. Analysis of survival factors of subcontractors in economic recession. In: Sandanayake, Y.G., Gunatilake, S. and Waidyasekara, A. (eds). Proceedings of the $8^{\text {th }}$ World Construction Symposium, Colombo, Sri Lanka, 8-10 November 2019, pp. 66 -76. DOI: doi.org/10.31705/WCS.2019.7. Available at: https://2019.ciobwcs.com/papers

\title{
ANALYSIS OF SURVIVAL FACTORS OF SUBCONTRACTORS IN ECONOMIC RECESSION
}

\author{
A.S.M. Misbah ${ }^{1}$, Vijitha Disaratna ${ }^{2}$, Pavithra Ganeshu ${ }^{3}$ and F.S. Nazeer ${ }^{4}$
}

\begin{abstract}
Subcontracting is a term which means giving a portion of the work or obligations to another party called as subcontractor (SC) under a contract. This was used in several industries but in the construction industry, it plays a vital role to complete the project with a higher quality of output. In gross domestic product (GDP) calculation of the national economy, the significance of the construction industry is very high. When a country faces an economic recession, it has a direct impact on the construction industry and the stakeholders of that industry. A small number of researches was available regarding how the construction firms handle the external changes like economic recession. In this respect, this research analyses the key strategies used by the SCs when they face an economic recession. Purposive sampling method was used for data collection and a questionnaire survey was selected as the basic technique to collect data. The respondents were first asked about their profile and then about the effect of recession and survival strategies in economic recession. Relative Importance Index (RII) method was used to rank the effects and the strategies according to its importance given by the respondents. Findings of the research were that there are various strategies which are most important to the survival of subcontracting firms "Increasing the focus on forming relationship with main contractors", "maintain goodwill to get additional financial support from bank", "Implementing stricter site management to reduce material and time wastage", "Implementing stricter financial management on company cash flow", and "bidding for more projects that are within the firm's resources and capabilities". Finally, practicable suggestions were identified for SCs to survive in the construction industry during the economic recession period.
\end{abstract}

Keywords: Economic Recession; Key Strategies; Subcontractors (SC); Survival Factors.

\section{INTRODUCTION}

The most changing and challenging industry is the construction industry facing more risk and uncertainty compared to other industries. Furthermore, according to Thevendran and Mawdesley (2004) construction industry has risks and obviously, it is felt in construction projects. According to Poh and Tah (2006), various types of risks are experienced by the construction projects regularly and moreover, Kangari (1995) stated that it affects the productivity, performance, quality, and budget of a construction project. However, risks are inevitable (Zou et al., 2007). As reported by Kangari (1995) risk can be minimized or

\footnotetext{
${ }^{1}$ Department of Building Economics, University of Moratuwa, Sri Lanka

${ }^{2}$ Department of Building Economics, University of Moratuwa, Sri Lanka, vijithad@uom.lk

${ }^{3}$ Department of Building Economics, University of Moratuwa, Sri Lanka, sunganesh21@gmail.com

${ }^{4}$ Department of Building Economics, University of Moratuwa, Sri Lanka, sabrinanazeer@gmail.com
} 
transferred from one stakeholder to other stakeholders in the construction process. Thus, to manage all types of risks there should be a risk management process in construction projects (El-Sayegh, 2008).

According to Baynes (2008), Gross Domestic Product (GDP), which is the market value of all final goods and services produced within an economy at a given period of time, is considered the broadest indicator of economic output. The construction industry contributes more than 6.4\% to the GDP in Sir Lanka (Central Bank of Sri Lanka, 2008). People involved in the construction project are owners, designers, construction main contractors (MC), subcontractors (SC), maintenance contractors, and material suppliers, etc. (Moore et al., 1992). Nature of the modern construction technology, size and scale are moving towards more specific and complex. Therefore, the $\mathrm{MC}$ is willing to subcontract the work due to their lack of skill and knowledge and resources (Chamara, 2011). Subcontracting is defined as the arranging and applying of the tasks that differ from the main activity of the contractor, supply materials, equipment, and manpower are few tasks of SC's (Gonzalez-Diaz et al., 2000). Piyasoma (1994) had found that more than $80 \%$ of specialized works were done by the SCs in Sri Lanka.

Therefore, subcontractors are very important to consider in the Sri Lankan economy. Subcontractor's survival in an economic recession is very important to the construction industry. There was no existing study focus on the surviving strategy of subcontractors in the economic recession. This study focuses on this gap. This paper initially provides a comprehensive literature review in order to identify the strategies taken by the SCs to survive in economic recession times. Then the findings of the questionnaire surveys are presented and further subjected to a discussion. Finally, conclusions are drawn from the findings.

\section{IMPORTANCE OF THE CONSTRUCTION INDUSTRY}

A country has several sectors that contribute to the economy and depending on the resources distribution; these sectors might change from country to country. The construction sector can be identified as a contributor to the economy in almost every country in the world. Gross Domestic Product (GDP) of a country is considered one of the most successful macro-economic indicators. By determining the contribution of every sector to the GDP we can understand its contribution to the economy.

\subsection{DEFINITION FOR SUBCONTRACTOR}

Most of the construction projects undertaken are more complex in nature, demanding greater skill and technologies, fast track and concurrent works practices. Further, they are very competitive in terms of price, demanding end product quality and good decisionmaking skills, capabilities in utilizing knowledge management and very critical in dealing with contractual issues than ever before (Manoharan, 2005). As a result, it requires many specialist consultants and contractors to be employed in projects. In a situation like this, a single main contractor cannot possibly handle all related project tasks. As Manoharan (2005) further mentioned the client awarded the works to the contractor, and then the contractor will have engaged a few companies called "SC" to carry out the works according to the work assigned. It has created a circumstance for SCs to involve in construction projects. Arditi and Chotibhongs (2005) indicated that SC is a construction firm that contracts with the main contractor to perform some aspects or special aspects of the main contractor's work. Unlike main contractors, an SC is an individual or in many 
cases a business that signs a contract to perform a special part or all of the obligations of another's contract. SC can also sublet the projects within other contractors.

\subsection{RISK IN CONSTRUCTION INDUSTRY}

Construction projects have more inherent risks due to the involvement of many contracting parties such as owners, designers, contractors, SCs, suppliers, etc. Construction projects are unique and built only once. It also involves a temporary project team that is assembled from different companies, countries, cultures, etc. Moreover, the size and complexity of construction projects are increasing which adds to the risks.

Risks may come from various sources in the construction project which is always unique (Oyegoke, 2006). Construction industries do always have more and more Risks and uncertainties when compared to other industries. It has the complex and time-consuming process of planning, executing and maintaining. Many main contractors are forced to rely heavily on subcontracting to minimize their risks due to the unpredictable workloads and a need for a multitude of specialized skills Beardsworth et al. (1988). According to Richter and Mitchell (1982) subcontracting the work to those who have the necessary resources to perform the work done efficiently and economically does help the main contractors in obtaining a higher profit margin by reducing their workload.

\subsection{DEMAND FOR SUBCONTRACTOR's WORK}

SCs practice an important segment of the construction industry work in the current construction market. Main contractors are provided with the chance of minimizing the required resources, with the help of SCs, and they are provided with specialized expertise in construction projects. This makes the main contractors to rely on SCs to carry out the construction work, and it helps to increase the demand for subcontracting organizations (Mbachu, 2008). As per Hartmann and Caerteling (2010) in the Netherlands context up to $90 \%$ of the total value of a construction project, SCs supply labor, and material facility. The performance of the SCs determines the ability of the main contractor and consultants to deliver the project within time, quality and cost targets. Further, Mbachu (2008) explained expectable reasons for subcontracting as below.

- Expected high quality of works, since SCs are seen as 'specialists' in their own fields

- The main contractor's margin and costs are known from the commencement of the contract through the SCs' quotations

- The main contractor passes on the risks and responsibilities of redeployment, hiring and firing of subcontracting workers on to the SCs

- Cash flow problems and the challenge of financing the project are all eased by the use of SCs

- The main contractor's overheads commitment in the form of supervision, office staff, accommodation, etc., can be reduced significantly when working with reliable SCs

\subsection{STRATEgIES TAKEN BY SUbCONTRACTORS TO SURVIVE DURING RECESSION}

For the survival of economic downtrend, construction firms can be able to use various kinds of schemes to help them. 


\section{- Financial capital}

There are some situations that indicates the importance of having own finance. Having finance for paying to the material in advance, manpower, and tools sent to the building site (Palaneeswaran et al., 2009). The payment period is much shorter than their regaining period. Especially the wages of workers are paid within 30 days (Arditi et al., 2000). In conclusion, the extra financial costs, additional financial support is needed by the subcontractors (Arditi and Chotibhongs, 2005).

- Demand

From the demand side, there is a clear downward pressure on costs in a crisis scenario. In the long run, there is no sustainability in the downstroke of the price. Selling products at lower costs will cause a difficult situation in more professionalized companies (Schleifer, 1990), with or without knowing. This can be broken to get the mutual interest of parties because the client always wants the cheapest.

- Geographic scope

The subcontractors performing best according to their geographical scope even in the crisis scenario. Internationalization is the word mostly pronounced in trend. Generally, a consideration to extending the scope has been taken by the stakeholders such as developers, engineers, subcontractors and suppliers (Martin and Gonzalez, 2010). The scope of the local companies extended along with the whole country and the larger ones have become international (Schleifer, 1990).

- Managerial assets

The systematic management process is not followed by the subcontractors usually in their construction sites. Furthermore, the main competitive advantages in business management is the flexibility which is deliberated by the subcontractors. These actions are practicable because SCs are smaller in business with an organization and the powers are centralized with the owner or CEO (Arditi et al., 2000).

- Relationship assets

There are main factors to get a project which are, the establishment of the relationships of trust in the part of the subcontractor's corporate image (Kumaraswamy and Mathews, 2000), and relationship with the main contractor in past projects (Palaneeswaran et al., 2009). In the project-delivery-method category it is partly contrary that when awarding subcontract, the price is the key factor (Ling et al., 2010). Therefore, to bid a contract and qualify, these "trusting relationships" can be considered as a qualification.

\section{RESEARCH METHOD}

The research initiated with a literature synthesis to identify the strategies taken by SCs during economic recession times. The research approach for this study was mainly a quantitative approach. The selection of the research approach for this study was justified through the following reasons such as the research is to identify and establish a generalized opinion of a society, in an objective manner without any in-depth investigation; a large number of possible respondents and the research question which attempts to identify "What are the factors that help to survive the subcontractors in recession?". By considering the circumstances of this particular research, especially 
neediness of the identification and perceptions of construction industry practitioners about the survival factors among subcontract parties, a questionnaire survey was selected as the basic technique to collect data and convenience non-probability sampling was used as a method of sampling.

Data obtained through the detailed questionnaire survey was analyzed using the Relative Importance Index (RII). RII is identified as a data analysis technique used to rank the factors and identify the most significant factors by many researchers (El-Sayeh, 2008). Furthermore, the selection of RII is justified as this study intends to rank the survival factors.

\section{DATA ANALYSIS AND FINDINGS}

During the data collection stage, a purposive sampling technique was used as this study need to focus on special groups such as subcontracting firms and few main contracting firms. The questionnaires were filled by thirty-eight responders. There were a total of thirty-one strategies identified to analyze in the questionnaire and those strategies were categorized as per project size, forward agreements with suppliers and SCs, bid margin strategies, specialization, relationship, marketing, and new work sources, diversification, cost reduction, employment, financial resources and fulfillment with training.

\subsection{ProJect Size}

The first three strategies of the questionnaire asked for responses to project size. Of those strategies, fifteen respondents filled "Bidding for more projects that are within the firm's resources and capabilities" as very important and most important and seventeen respondents filled as important. As shown in Table 1, the mean of the strategy was 3.29 and RII was $65.79 \%$. The respondents described that their "strike rate", the secured project which had relation with their priced was reduced dramatically during the economic recession period. Because of that, they thought this strategy was important.

Table 1: Results for project size strategies

\begin{tabular}{lcc}
\hline \multicolumn{1}{c}{ Strategy } & Mean & RII (\%) \\
\hline $\begin{array}{l}\text { Bidding for more projects that are within the firm's resources and } \\
\text { capabilities }\end{array}$ & 3.29 & 65.79 \\
$\begin{array}{l}\text { Targeting smaller than usual contracts. } \\
\text { Setting limits on project size so that any failure of one project }\end{array}$ & 2.66 & 53.16 \\
would not harm the firm's operation. & 2.39 & 47.89 \\
\hline
\end{tabular}

\subsection{FORWARD AGREEMENTS WITH SUPPLIERS AND SCS}

In this category, the fourth strategy of the questionnaire was asked to fill from the respondents who were "Entering into forward contracts with suppliers and subcontractors to protect the firm against cost escalation". This strategy had a mean rating of 2.82 and the RII of 56.38\%. eleven respondents had identified this strategy as not important or slightly important because most SC's works are tendered and it makes difficult to predict their upcoming resource requirements. But nine respondents identified this as very important or most important (refer Table 2). 
Table 2: Results for forward agreements with suppliers and SCs strategies

\begin{tabular}{lcc}
\hline \multicolumn{1}{c}{ Strategy } & Mean & RII (\%) \\
\hline $\begin{array}{l}\text { Entering forward contracts with suppliers and } \\
\text { subcontractors to protect the firm against cost escalation }\end{array}$ & 2.82 & 56.38 \\
\hline
\end{tabular}

\subsection{SPECIALISATION}

In this category, the seventh and eighth strategies of the questionnaire were asked to fill from the respondents which were regarding fast track projects and specializing in expertise. Those strategies had a mean rating with 2.79, 3.21 and with RII of 55.79, 64.29 respectively (refer Table 3). Furthermore, twelve respondents replied as very important or most important and ten respondents replied as important to the short term and fast track project strategy. Moreover, thirty-four respondents replied as important or very important.

Per a few respondent's views, if an SC specialized in a specified work when the MC could have the work, MC can be picking up those specialized SCs to the projects the SC specialized in.

Table 3: Results for specialization strategies

\begin{tabular}{lcc}
\hline \multicolumn{1}{c}{ Strategy } & Mean & RII (\%) \\
\hline Undertaking short-term and fast track projects & 2.79 & 55.79 \\
Specializing in a particular expertise & 3.21 & 64.29 \\
\hline
\end{tabular}

\subsection{RELATIONSHIP}

In this category, from ninth to fourteenth strategies asked for response from respondents which had a relationship with both other SCs and clients of SCs. Table 4 shows the mean rating of each relationship strategy and the RII of each relationship strategy.

Table 4: Results for relationship strategies

\begin{tabular}{lcc}
\hline \multicolumn{1}{c}{ Strategy } & Mean & RII (\%) \\
\hline Subcontracting work from other SCs & 1.79 & 35.79 \\
Acquiring projects from defunct companies & 1.39 & 27.89 \\
Forming joint ventures with other SCs & 2.24 & 44.74 \\
Forming partnership with MC & 2.84 & 56.84 \\
Forming partnership with construction clients & 3.05 & 61.05 \\
Increasing the focus on forming relationships with MC & 3.84 & 76.84 \\
\hline
\end{tabular}

"Forming partnership with main contractor" had a mean rating of 2.84 and with the RII of 56.84. Ten respondents identified this strategy as not important or slightly important and ten respondents identified as very important or most important. So, the respondents had mixed feelings for this strategy. Some respondents mentioned that this strategy was good for SCs to secure the works before pricing and both parties, MC and SC will feel better by working together as they wanted out of the partnership.

Dainty et al. (2001) mentioned that, on supply chain alliances between SC and MC, the response from SCs was that MC's didn't fully comprehend the idea of partnering and the 
reasons MCs undertook the practice was for their own good only. In this respect, few respondents said, the MCs may accept the lowest price or try to make partnership to their advantage at the expense of the SC.

The fourteenth strategy of the questionnaire "Increasing the focus on forming relationships with MCs" had the highest mean rating and the RII of 3.84, 76.84 respectively. Most of the respondents rated this strategy as either very important or most important in the scale of the questionnaire. The respondents mentioned in order to ensure the survival of SC's business', they should maintain a good relationship with others. This relationship will give the information about the new work and if once established the relationship with MC, they know each other's business works and they work better together with fewer problems regarding money or payments.

\subsection{MARKeTING AND NeW WORK SOURCES}

The fifteenth and sixteenth strategy of the questionnaire asked for responses which were "increasing time/ expenditure on marketing" and "Trying to break into new sources of work" (refer Table 5).

Table 5: Results for marketing and new work sources strategies

\begin{tabular}{lcc}
\hline \multicolumn{1}{c}{ Strategy } & Mean & RII (\%) \\
\hline Increasing time/ expenditure on marketing & 2.84 & 56.84 \\
Trying to break into new sources of work & 2.74 & 54.74 \\
\hline
\end{tabular}

The "increasing time/ expenditure on marketing" had a mean of 2.84 and the RII was 56.84. The respondents stated that during the recession period SCs will increase their time and expenditure on marketing like giving radio advertisements. It will be very effective to increase their brand awareness in the business market. However, this marketing strategy was not rated as great. Because most of the respondent's points of view, the money spent on marketing their business would be better to spend on strengthening their relationships.

The remaining strategy in this category, "Trying to break into new sources of work" had a mean rating of 2.74 and the RII was 54.74. This strategy had a low mean rating because when considering this strategy, the SCs can lowering their price to a large amount of work to break into new sources of work to work under another MC. If they did as like that they could win. However, that $\mathrm{MC}$ already dominated by strong relationship with their own $\mathrm{SC}$ who is completely competitor to the new SC, even though the new SC had a chance to win, the works would be given to their opposition or MC's own SC.

\subsection{COST REDUCTION}

In this category, the twentieth and twenty-first strategies of the questionnaire were asked to fill from the respondents (refer Table 6).

Both the strategies in this category had a relatively high mean rating and RII. "Implementing stricter site management to reduce material and time wastage" had a mean rating of 3.53 and the RII of 70.53 which was third higher rank. Most of the respondents said that their companies always try to achieve this strategy. During the recession period without implementing stricter site management to reduce the wastages will harm the 
firm's operation and it should become a more pressing issue. No matter how much work is on for a day but the firm should control day to day work themselves.

Table 6: Results for cost reduction strategies

\begin{tabular}{lcc}
\hline \multicolumn{1}{c}{ Strategy } & Mean & RII (\%) \\
\hline $\begin{array}{l}\text { Implementing stricter site management to reduce material and time } \\
\text { wastage }\end{array}$ & 3.53 & 70.53 \\
Implementing stricter financial management on company cash flow & 3.42 & 68.42 \\
\hline
\end{tabular}

When it came to "Implementing stricter financial management on company cash flow" it had a fourth higher ranking of mean rating and RII of 3.42, 68.42 respectively. As per some respondent's point of view, the SCs should change their rules related to purchasing and the subcontracting firms should allow only senior staff to purchase goods for a certain value or the proper approval should be made before purchasing goods by anyone. Lack of controlling financial aspects causes the construction firm's failure (Mutti and Hughes, 2002).

\subsection{FinANCIAL RESOURCES}

In this category, the twenty-ninth and thirty-first strategy of the questionnaire were analyzed.

As shown in Table 7, "maintain goodwill to get additional financial support from banks" had the second-highest mean rating and RII of 3.61, 72.11 respectively. More than thirty respondents responded as very important or most important to this strategy.

Table 7: Results for financial resources strategies

\begin{tabular}{lcc}
\hline \multicolumn{1}{c}{ Strategy } & Mean & RII (\%) \\
\hline $\begin{array}{l}\text { Find a minor financial consulting firm to do financial } \\
\text { management and accounting services as outsourcing }\end{array}$ & 2.47 & 49.47 \\
Maintain goodwill to get additional financial support from banks & 3.61 & 72.11 \\
\hline
\end{tabular}

As per most of the respondent's point of view, maintaining good behaviour and reliable transactions are not only helping to get additional financial supports from banks, it is important to increase the customer base and to retain their old clients and new opportunities will be formed if the firm has longstanding business goodwill. Furthermore, if the firm's representative made any trouble, the MC or client was giving forgiveness because of their trust through SC's previous experience.

\subsection{FULFILMENT WITH TRAINING}

In this category, the remaining strategy was discussed which was "get adequate skilled persons with appropriate training". This strategy had a mean of 2.82 and the RII was 56.32 as shown in Table 8.

Table 8: Results for fulfillment with training strategies

\begin{tabular}{ccc}
\hline Strategy & Mean & RII (\%) \\
\hline Get adequate skilled persons with appropriate training & 2.82 & 56.32 \\
\hline
\end{tabular}


This strategy was a bit important because some respondents said that business improvement is made by the training and it helps to increase the profit and staff morale. But few respondents said that it may be difficult to find skilled persons because their existing firm will not lose them. Nevertheless, the firm should give additional allowances to get them from their existing firm.

\subsection{IMPORTANT SURVIVAL STRATEGIES}

As per the RII analysis, the following strategies (refer Table 9) are filtered as important strategies for SC to survive during economic recession times.

Table 9: Filtered strategies

\begin{tabular}{|c|c|c|c|}
\hline Nr. & Strategy & RII & Ranking \\
\hline 01 & $\begin{array}{l}\text { Increasing the focus on forming relationships with main } \\
\text { contractors }\end{array}$ & 76.84 & 01 \\
\hline 02 & $\begin{array}{l}\text { Maintain goodwill to get additional financial support from } \\
\text { banks }\end{array}$ & 72.11 & 02 \\
\hline 03 & $\begin{array}{l}\text { Implementing stricter site management to reduce material and } \\
\text { time wastage }\end{array}$ & 70.53 & 03 \\
\hline 04 & $\begin{array}{l}\text { Implementing stricter financial management on company cash } \\
\text { flow }\end{array}$ & 68.42 & 04 \\
\hline 05 & $\begin{array}{l}\text { Bidding for more projects that are within the firm's resources } \\
\text { and capabilities }\end{array}$ & 65.79 & 05 \\
\hline 06 & Specializing in a particular expertise & 64.29 & 06 \\
\hline 07 & Forming partnership with construction clients & 61.05 & 07 \\
\hline 08 & Increasing time/ expenditure on marketing & 56.84 & 08 \\
\hline 09 & Forming partnerships with main contractor & 56.84 & 08 \\
\hline 10 & $\begin{array}{l}\text { Entering into forward contracts with suppliers and } \\
\text { subcontractors to protect the firm against cost escalation }\end{array}$ & 56.32 & 10 \\
\hline 11 & Get adequate skilled persons with appropriate training & 56.32 & 10 \\
\hline 12 & Undertaking short-term and fast track projects & 55.79 & 12 \\
\hline 13 & Trying to break into new sources of work & 54.74 & 13 \\
\hline 14 & Targeting smaller than usual contracts & 53.16 & 14 \\
\hline 15 & Employing on contract basis & 50.53 & 15 \\
\hline
\end{tabular}

The above strategies can be used as strategies to survive while economic recession. All of them can be implemented practically in the current construction industry without any limitations. As these have easy implementation features all kin of subcontractors can follow these without any hesitation.

\section{CONCLUSIONS}

The economic recession of the country is one of the major risks to the construction industry and it has a direct effect on the construction industry as exposed in the literature review. To survive from that risk, construction firms should handle alterations and strategies. There is no research found on the analysis of survival factors during the recession period for the construction firms in the Sri Lankan construction industry. 
Therefore, this research focused on subcontracting firms due to the wideness of the area. The study was fulfilled with the questionnaire which was to identify the strategies that can be taken by the Subcontractors to survive during the recession period. All of these findings are practicable and very easy to implement. All kinds of subcontractors with different grades also can be implemented these things. Increasing the focus on forming relationships with main contractors, maintaining goodwill to get additional financial support from banks, implementing stricter site management to reduce material and time wastage are the most important strategies to follow in the economic recession.

\section{REFERENCE}

Arditi, D., and Chotibhongs, R., 2005. Issues in subcontracting practices. Journal of Construction Engineering and Management, 131(8), pp.866-876.

Arditi, D., Koksal, A., and Kale, S., 2000. Business failures in the construction industry. Engineering Construction and Architectural Management, 7(2), pp.120-132.

Baynes, R., 2008. Economic indicators: Gross Domestic Product (GDP) [online]. http://www.investopedia.com/contributors [Accessed 03 March 2019].

Beardsworth, A., Keil, E., Bresnen, M., and Bryman, A., 1988. Management transience and subcontracting: The case of the construction site. Journal of Management Studies, 25(6), pp.603-625.

Central Bank of Sri Lanka., 2008. Annual Report. Central Bank of Sri Lanka.

Chamara., 2011. Evaluating subcontractor's approach in construction project. Thesis (B.Sc). University of Moratuwa.

Dainty, A.R., Briscoe, G.H., and Millett, S.J., 2001. Subcontractor perspectives on supply chain alliances. Construction Management and Economics, 19(8), pp.841-848.

El-Sayegh, S., 2008. Risk assesment and allocation in the UAE construction industry. International Journal of Project Management, 26(4), pp.431-438.

Gonzalez-Diaz, M., Arrunada, B., and Fernandez, A., 2000. Causes of subcontracting: Evidence from panel data on construction firm. Journal of Economic Behavior \& Organization, pp.167-187.

Hartmann, A., and Caerteling, J., 2010. Subcontractor procurement in construction: The interplay of price and trust. Supply Chain Management: An International Journal, 15(5), pp.354-362.

Iqbal, A., and Vitner, M., 2011. The deeper the recession, the stronger the recovery: Is it really that simple? Bus Econ, 46(1), pp.22-31.

Kangari, R., 1995. Risk Management Perceptions and Trends of U.S. Construction. Journal of Construction Engineering and Management, 121(4), pp.422-429.

Kumaraswamy, M., and Mathews, J., 2000. Improved subcontractor selection employing partnering principles. Journal of Management in Engineering, 16(3), pp.47-57.

Teck Heng Lim, B., Lan Oo, B., and Ling, F., 2010. The survival strategies of Singapore contractors in prolonged recession. Engineering, Construction and Architectural Management, 17(4), pp.387-403.

Manoharan, R., 2005. Subcontractor selection method using analytic hierachy process. Thesis (M.Sc), Universiti Teknologi, Malaysia.

Martin, R., and Gonzalez, J., 2010. The strategic repositioning of Spanish construction companies. Construction Reports, 62(520), pp.67-84.

Mbachu, J., 2008. Conceptual framework for the assessment of subcontractors' eligibility and performance in the construction industry. Construction Management and Economics, 26(5), pp.471-484.

Moore, C., Mosley, D., and Slagle, M., 1992. Partnering guidelines for win-win project management. Project Management Journal, 22 (1), pp.18-21.

Mutti, N., and Hughes, W., 2002. Cash flow management in construction firms. In: Greenwood, D. (ed.). $18^{\text {th }}$ annual ARCOM conference. Northumbria: Association of Researchers in Construction Management, pp.23-32.

Oyegoke, A., 2006. Construction industry overview in the UK, US, Japan and Finland: A comparative analysis. Journal of Construction Research, 7(1\&2), pp.13-31. 
Palaneeswaran, E., Tang, Z., and Thomas , N., 2009. Factors contributing to the success of equipmentintensive subcontractors in construction. International Journal of Project Management, 27(7), pp.736744.

Piyasoma, W., 1994. Interaction between main contractor and subcontractor in construction project. Thesis (B.Sc), University of Moratuwa.

Poh, Y., and Tah, J., 2006. Integrated duration-cost influence network for modelling risk impacts on construction tasks. Construction Management and Economics, 24(8), pp.861-868.

Richter, I., and Mitchell, R., 1982. Handbook of construction law and claims. Reston, Virginia: Reston Pub. Co.

Schleifer, T., 1990. Construction contractors' survival guide. New York: Wiley.

Thevendran, V., and Mawdesley, M., 2004. Perception of human risk factors in construction projects: An exploratory study. International Journal of Project Management, 22(2), pp.131-137.

Zou, P., Zhang, G., and Wang, J., 2007. Understanding the key risks in construction projects in China. International Journal of Project Mangement, 25(6), pp.601-614. 